EWA M. ZIÓŁEK*

Instytut Historii

Katolicki Uniwersytet Lubelski Jana Pawła II

ORCID: 0000-0003-0167-5491

\title{
MIĘDZY TRADYCJĄ A NOWOCZESNOŚCIĄ? SENAT W KSIĘSTWIE WARSZAWSKIM I KRÓLESTWIE POLSKIM (WYBRANE PROBLEMY)
}

\author{
Between tradition and modernity? The Senate in the Duchy of Warsaw \\ and the Kingdom of Poland (selected problems)
}

Abstract

The article discusses the place of the senate in the constitutional systems of the Duchy of Warsaw and the Kingdom of Poland, with references to the traditional model of the Polish Sejm, and the innovations in this system. These resulted from the imposition of the French model of legislation in 1807 and next from the need to comply with the regulations of the Congress of Vienna of 1815. Both constitutions of the Duchy of Warsaw and of the Kingdom of Poland, were imposed from the outside and aimed at creating a system suitable for a non-sovereign state, consistent with the order created by European powers. Nevertheless, some references to the Polish constitutional tradition appeared in the constitutions, which had a rather propaganda dimension towards Polish subjects.

Keywords: Duchy of Warsaw, Kingdom of Poland, Polish parliamentarism, Senate

\begin{abstract}
Abstrakt
Artykuł omawia zagadnienie umiejscowienia senatu w systemie ustrojowym Księstwa Warszawskiego i Królestwa Polskiego i nawiązania do modelu tradycyjnego polskiego sejmu oraz innowacje $\mathrm{w}$ tym systemie. Wynikały one z narzucenia modelu francuskiej legislacji w 1807 r., a potem konieczności podporządkowania się ustaleniom kongresu wiedeńskiego 1815 r. Obie konstytucje - Księstwa Warszawskiego i Królestwa Polskiego, narzucone z zewnątrz, miały na celu stworzenie ustroju odpowiedniego dla niesuwerennego państwa, wpisywanego w porządek tworzony przez mocarstwa europejskie. Mimo to w konstytucjach

* Dr hab. Ewa M. Ziółek, Katedra Historii XIX wieku, Instytut Historii Katolickiego Uniwersytetu Lubelskiego Jana Pawła II. Zajmuje się historią Polski i powszechną XVIII i XIX w., relacjami państwowo-kościelnymi w tym okresie. Autorka dwóch monografii, kilkudziesięciu artykułów i kilku wydawnictw źródłowych. E-mail: ewamargo@kul.lublin.pl.
\end{abstract}


pojawiły się pewne odniesienia do polskiej tradycji ustrojowej, co miało raczej wymiar propagandowy wobec polskich poddanych.

Słowa kluczowe: Księstwo Warszawskie, Królestwo Polskie, parlamentaryzm polski, senat

Podejmując powyższe zagadnienie należy uczynić podstawowe wstępne założenie, że powstałe w wyniku traktatu tylżyckiego w 1807 r. Księstwo Warszawskie, podobnie jak utworzone na mocy postanowień kongresu wiedeńskiego w 1815 r. Królestwo Polskie, były to twory całkowicie niesuwerenne. Pierwsze, połączone unią personalną z Saksonią, było w istocie satelitą napoleońskim, drugie - zależne od Rosji. Jeśli więc nie można mówić o państwie suwerennym, to również należy przyjąć, że o kształcie ustrojowym nie decydowali Polacy, ale obce mocarstwa i to według własnych potrzeb, a nie zgodnie z wielowiekową polską tradycją ${ }^{1}$.

\section{Senat w Księstwie Warszawskim}

W odczuciu społecznym Księstwo Warszawskie uznawane było jednak za początek odbudowywania Rzeczypospolitej po 11 latach od ostatniego rozbioru, czego nie da się powiedzieć o Królestwie Polskim. Ustrój Księstwa określił Napoleon w nadanej przez siebie 22 lipca 1807 r. konstytucji, opartej zasadniczo na wzorach legislacji francuskiej, jednak z dodatkiem pewnych elementów mających wskazywać na zachowanie ciągłości pomiędzy Polską przedrozbiorową i Księstwem właśnie. Mając świadomość znaczącej siły politycznej magnaterii, jak też przywiązania szlachty do Konstytucji 3 Maja, zgadzał się na takie nawiązania do Ustawy Rządowej, które nie były sprzeczne z ustrojem, jaki zamierzał wprowadzić w Księstwie. Stąd powołanie na tron księcia warszawskiego Fryderyka Augusta, króla Saksonii, czy wysoka pozycja Stanisława Małachowskiego oraz innych uczestników Sejmu Wielkiego. Napoleon ewidentnie oparł się na starej elicie władzy, nie na radykałach np. związanych z lewicą powstania kościuszkowskiego, czyli tzw. jakobinach polskich.

Wobec tego inne było w Księstwie umiejscowienie senatu w stosunku do senatów we Francji czy innych krajach ówcześnie podległych francuskiej dominacji. Senat francuski był w pewien sposób niezależny od pozostałych organów władzy. Jego skład liczył początkowo 60 członków, następnie wzrósł do 80 i pochodził z kooptacji. Posiadał uprawnienia

\footnotetext{
1 W niniejszym artykule nie zostaną omówione wszystkie aspekty wiążące się z problematyką senatu, którą trzeba zresztą rozpatrywać w powiązaniu z systemem parlamentarnym w Księstwie Warszawskim czy też Królestwie Polskim oraz zagadnieniami ustrojowymi. Nie zostanie także podjęta problematyka relacji zachodzących pomiędzy dwiema izbami parlamentu, z uwagi na to, że stanowi to na tyle szerokie zagadnienie, że należałoby mu poświęcić osobną publikację. Zostanie natomiast zwrócona uwaga na kwestię zmian oraz powracania do modelu tradycyjnego. Zresztą w odniesieniu do problematyki ustrojowej istnieje znaczna literatura przedmiotu. Zob. np.: M. Kallas, Konstytucja Księstwa Warszawskiego. Jej powstanie, systematyka i główne instytucje w związu z normami szczegółowymi i praktyka, Torun 1970; W. Sobociński, Historia ustroju i prawa Księstwa Warszawskiego, Toruń 1964; W. Rostocki, Z badań porównawczych nad ustrojem administracyjnym Księstwa Warszawskiego i Francji, „Czasopismo Prawno-Historyczne”, 13/1961, z. 1, s. 105-126; J. Czubaty, Księstwo Warszawskie (1807-1815), Warszawa 2011, s. 136-150; M. Getka-Kenig, Ojcowie ,, wskrzeszonej” ojczyzny. Senat w rzeczywistości społeczno-politycznej Księstwa Warszawskiego, Warszawa 2013; A. Ajnenkiel, Historia sejmu polskiego, t. 2, cz. 1: W dobie rozbiorów, Warszawa 1989; P. Łazor, Senat w Królestwie Polskim (1815-1830). Organizacja, kompetencje i funkcjonowanie, w.: System polityczny, prawo i konstytucja Królestwa Polskiego 1815-1830, red. L. Mażewski, Radzymin 2013, s. 347-359.
} 
wyborcze: dokonywał wyboru członków ciała prawodawczego, trybunatu, konsulów, sędziów kasacyjnych i komisarzy rachunkowych z listy narodowej. Do jego kompetencji należała kontrola zgodności z konstytucją aktów prawnych. Ponadto posiadał specjalne prerogatywy wyrażające się w tzw. senatus consultum, umożliwiające wprowadzanie pewnych rozwiązań prawno-ustrojowych z pominięciem drogi legislacyjnej. Obrady były niejawne ${ }^{2}$. Senat Księstwa natomiast pozostał drugą izbą parlamentu, obok izby poselskiej, choć już nie mówiono o 3 stanach sejmujących. Co więcej, konstytucja, będąc tworem francuskiej legislacji, całkowicie nie rozumiejącej istoty republikańskiego systemu Rzeczypospolitej, wzmocniła ogromnie władzę wykonawczą, kosztem ustawodawczej, co musiało odbić się także na roli senatu ${ }^{3}$. Jego prerogatywy omawiał Tytuł V konstytucji w artykułach 23-344. W ich myśl w senacie miało zasiadać: 6 biskupów, 6 kasztelanów i 6 wojewodów. Widać na pierwszy rzut oka, że konstytucja Księstwa ograniczała wyraźnie liczbę senatorów z około 130 na Sejmie Wielkim do 18. Wynikało to z utrzymania pozostałego po pruskim panowaniu podziału administracyjnego na 6 departamentów. Wojewodowie i kasztelanowie nie reprezentowali jednak poszczególnych departamentów, zatem w tym stanie tylko 6 biskupów stanowiło nawiązanie do przedrozbiorowego składu senatu ${ }^{5}$. Świeccy senatorowie bowiem nie pełnili rzeczywistych funkcji administracyjnych. Od tego momentu ich godności stały się wyłącznie honorowe, nadawane przez monarchę za zasługi dla kraju. W senacie nie zasiedli też jacykolwiek urzędnicy pełniący aktualnie funkcje. Natomiast sztywna liczba biskupów była wynikiem przeniesienia do konstytucji wzorów francuskich. W przeciwieństwie jednak do cesarstwa, na ziemiach polskich administracja państwowa i kościelna nie pokrywały się. W Księstwie istniało 7 diecezji ${ }^{6}$. Problem niezgodności liczby senatorów duchownych z konstytucją rozwiązano w ten sposób, że nie został powołany na wakującą od 1804 r. stolicę biskupią w Warszawie nowy biskup, tylko oddano ją w administrację abpowi gnieźnieńskiemu, Ignacemu Raczyńskiemu?. Oprócz Raczyńskiego do senatu weszli: bp nominat kujawski Franciszek Malczewski, bp poznański Tymoteusz Gorzeński, bp płocki Kajetan Onufry Szembek, a po jego śmierci, od 1809 bp nominat Tomasz Ostaszewski, bp chełmiński Franciszek Rydzyński oraz bp wigierski Jan Klemens Gołaszewski.

\footnotetext{
2 Należy pamiętać, że przepisy konstytucyjne we Francji ulegały w okresie panowania Napoleona Bonaparte pewnym zmianom, prowadzącym do stopniowo coraz większej zależności władzy ustawodawczej, w tym i senatu od I konsula, a od 1804 r. - cesarza. J. Godechot, Les institutions de la France sous la Révolution et l'Empire, Paris 1951, s. 478-479, 491-492, 498, 506 ; A. Zahorski, Napoleon - człowiek wieku, w: Europa i świat w epoce napoleońskiej, red. M. Senkowska-Gluck, Warszawa 1977, s. 56-60; M. Morabito, D. Bourmaud, Historia konstytucyjna i polityczna Francji (1789-1958), tłum. A. Jamróz, Białystok 1996, s. 185, 198-200.

J. Czubaty, dz. cyt. s. 143.

4 Dziennik Praw [Księstwa Warszawskiego], t. 1, Warszawa 1810, s. XII-XVI.

5 Jak się wydaje, dużą rolę w takiej interpretacji zapisów nowej konstytucji, które faktycznie zrywały w tym względzie z tradycją powiązania krzeseł senatorskich z poszczególnymi ziemiami (w tym wypadku - departamentami) odegrał Stanisław Kostka Potocki. Zwracał on uwagę, że konieczność sztywnego wyboru dwóch zasłużonych osób z każdego departamentu, przy założeniu, że powołani są oni do wyłącznie honorowej funkcji, powodowałaby niedogodność dla króla, ograniczanego w swojej prerogatywie, za jaką uznawano prawo do nagradzania osób zasłużonych, AGAD, Archiwum Publiczne Potockich, sygn.249, s.116-117. Słusznie zauważył M. Getka-Kenig (dz. cyt., s. 115-116), że cytowana notatka Potockiego świadczy o głębokiej świadomości elity politycznej Księstwa o naturalnym powiązaniu senatorstwa z poszczególnymi ziemiami i o podjęciu próby przełamania tradycji politycznej.

6 Były to: arcybiskupstwo gnieźnieńskie oraz diecezje: poznańska, kujawska, chełmińska, płocka, wigierska i warszawska.

7 E.M. Ziółek, Między tronem i oltarzem. Kościót i państwo w Księstwie Warszawskim, Lublin 2012, s. 58-59.
} 
Z wymienionych bp Gorzeński był uczestnikiem Sejmu Wielkiego. Po rozszerzeniu składu sejmu na mocy dekretu z 24 lutego 1810 r. ${ }^{8}$ w senacie przybyło dwunastu nowych członków po trzech z czterech nowych departamentów. Ostatecznie więc senat liczył 30 osób. Znów pojawił się problem z ilością diecezji, których w zdobytych departamentach galicyjskich było trzy. Tym razem poradzono sobie w ten sposób, że została przywrócona do istnienia diecezja chełmska - unicka9 ${ }^{9}$. Wobec tego z nowych departamentów w senacie pojawili się: bp krakowski Andrzej Gawroński, bp lubelski Wojciech Skarszewski, bp kielecki Wojciech Górski oraz Ferdynand Ciechanowski - bp chełmski. Z wymienionych uczestnikiem Sejmu Wielkiego był bp Skarszewski, który jednak w senacie Księstwa nie zasiadł, o czym będzie mowa w dalszej części.

Konstytucja Księstwa, czyniąc z senatu jedynie drugą izbę sejmu, ostatecznie znosiła model, w którym senat znajdował się pomiędzy władzą ustawodawczą a wykonawczą. Z drugiej jednak strony senatorów powoływał dożywotnio monarcha, podobnie to on wskazywał prezesa, ale tylko wówczas, gdy sam nie przewodniczył pracom senatu. Zachowano więc łączność monarchy z drugą izbą sejmu. Konstytucja Księstwa nie wprowadziła cenzusu wieku, oddając królowi całkowitą dowolność w kreowaniu senatorów. Najmłodszy z nich w chwili powołania, wojewoda Stanisław Zamoyski miał 34 lata $^{10}$. W przeciwieństwie do izby poselskiej, która obradowała co dwa lata przez dwa tygodnie, można powiedzieć, że senat obradował permanentnie. To wynikało nie tylko z dożywotności mandatu, ale też prerogatyw, które zostały mu przypisane. Co prawda prerogatywy sejmu, w stosunku do okresu przedrozbiorowego, zostały bardzo mocno ograniczone, właściwie wyłącznie do kwestii finansowych (pozostałe prawa wprowadzano mocą dekretów króla), niemniej wszystkie ustawy sejmowe musiały uzyskać sankcję senatu. W pewnych, opisanych przypadkach mógł on odmówić przyjęcia ustawy. Po pierwsze - gdyby nie została ona przyjęta zgodnie z wymogami formalnymi, po drugie - przy braku większości głosów oraz po trzecie - w wypadku sprzeczności z konstytucją lub gdyby przyjęcie ustawy zagrażało bezpieczeństwu kraju ${ }^{11}$. W tym ostatnim przypadku nie można było jej dalej procedować, w dwóch pierwszych król mógł nakazać izbie poselskiej usunięcie uchybień proceduralnych. Ale też król miał prawo wymóc na senacie przeprowadzenie pewnych decyzji, podwajając liczbę wojewodów i kasztelanów ${ }^{12}$. Ponadto król mógł wprowadzać ustawy mocą dekretów, więc zawsze miał możliwość obejścia decyzji senatu.

Do prerogatyw senatu, jeśli chodzi o proces legislacyjny, należały też tzw. ,rugi poselskie", które miały za zadanie sprawdzenie prawomocności wyboru zarówno posłów, jak i nieszlacheckich deputowanych ${ }^{13}$. Generalnie można powiedzieć, że senat pełnił więc funkcję kontrolną wobec izby poselskiej oraz stał na straży przestrzegania konstytucji w odniesieniu

\footnotetext{
8 Dziennik Praw..., t. 2, s. 129.

9 Przy czym należy pamiętać, że jej przywrócenie do życia nie tyle wiązało się z problemami konstytucyjnymi, ile z koniecznością zapewnienia właściwej opieki duszpasterskiej obywatelom Księstwa wyznania greckokatolickiego, a kwestia senatorstwa została rozwiązana trochę „przy okazji”, zob.: E. M. Ziółek, dz. cyt., s. 95-99.

10 M. Getka-Kenig, dz. cyt., s. 105.

11 Mówił o tym artykuł 28, Dziennik Praw..., t. 1, s. XII-XII.

12 Nie był to przepis, który można było stosować wielokrotnie, ponieważ król po takim zabiegu nie mógł już powoływać następnych senatorów, aż do momentu powrotu ich liczby do stanu przewidywanego konstytucją, tzn. do momentu śmierci nadliczbowych senatorów, artykuły 32-33, Dziennik Praw..., t. 1, s. XVI.

13 Dziennik Praw..., t. 1, s. 115.
} 
do niej. Jednocześnie należy podkreślić, że senatorowie mieli pełnić także funkcję doradczą wobec króla, co wynikało z formuły dekretu nominacyjnego ${ }^{14}$ oraz poniekąd także $\mathrm{z}$ faktu przewodniczenia obradom przez monarchę.

Konstytucja nałożyła na senat również obowiązek corocznego zatwierdzania listy uprawnionych do głosowania w zgromadzeniach gminnych niebędących ziemianami, duchownymi lub wojskowymi (ci podlegali sankcji innych organów: egzekutorów podatków, ministra spraw wewnętrznych i ministra wojny). Mógł też, w razie podejrzenia nadużyć, nakazać prefektom sporządzenie list ponownie. W myśl dekretu z 7 września $1808 \mathrm{r}^{15}$ senat miał stać na straży właściwego przebiegu tworzenia tychże list, szczególnie nadzorować, czy nie dochodzi do przejawów arbitralności urzędników układających je. Było to ważne, ponieważ na sejmikach i zgromadzeniach gminnych wybierano nie tylko reprezentantów do sejmu, ale też kandydatów do władz municypalnych czy sędziów pokoju. W powszechnym odbiorze senat był postrzegany jako podpora tronu, stojąca na straży przestrzegania konstytucji oraz wolności obywateli.

Pierwszych senatorów Fryderyk August powołał jeszcze w 1807 r. m.in. spośród grona osób wchodzących do Komisji Rządzącej. Pierwszym prezesem senatu został Stanisław Małachowski, a sekretarzem - Julian Ursyn Niemcewicz. Po śmierci Małachowskiego w 1809 r. prezesem senatu został Ludwik Gutakowski, a po nim Stanisław Kostka Potocki, co było czytelnym nawiązaniem do Sejmu Wielkiego, jako że byli oni uczestnikami tamtych obrad. Zresztą wśród senatorów, z racji wieku, znaczącą większość stanowili ludzie stawiający pierwsze kroki w działalności politycznej w okresie przedrozbiorowym, jak przykładowo Józef Wybicki. Należy też dodać, że dwaj biskupi: Tymoteusz Gorzeński i Wojciech Skarszewski byli senatorami jeszcze w czasach panowania Stanisława Augusta. W ich więc osobach uwidaczniała się również ciągłość tej instytucji ${ }^{16}$.

Pierwsze posiedzenie senatu w Księstwie Warszawskim odbyło się 2 XII 1808 r. co wiązało się z przygotowaniami do pierwszego posiedzenia sejmu, przewidzianego na marzec 1809 r. Odbyło się ono w czwartą rocznicę koronacji Napoleona, co symbolicznie miało stanowić wyraz wdzięczności dla cesarza. Wolą Fryderyka Augusta było, aby senat nawiązywał, na tyle, na ile było to możliwe, do tradycji przedrozbiorowej. Był to zabieg celowy, mający pokazać społeczeństwu ciągłość państwową. Temu służyło powołanie w skład izby uczestników Sejmu Wielkiego. Niemniej w największym stopniu to oczekiwanie mogło się odnosić do senatorów duchownych. Konstytucja Księstwa bowiem utrzymała zasadę, że biskup ordynariusz był senatorem. Artykuł 24 mówił: „Wojewodów i kasztelanów król mianuje. Biskupów król mianuje, a Stolica święta instytucją daje"17. Zapis ten Fryderyk August interpretował w taki sposób, jak było to praktykowane w okresie przedrozbiorowym,

\footnotetext{
14 M. Getka-Kenig, dz. cyt., s. 99.

15 Dziennik Praw..., t. 1, s. XXX-XXII (art. 59-60), dekret z 7 IX 1808 r. s. 78-115.

16 T. Gorzeński został w 1790 r. biskupem smoleńskim, dopiero w 1809 r. - z uwagi na zawirowania polityczne ostatecznie przeniesiony został z biskupstwa smoleńskiego na poznańskie, zob. J. Nowacki, Gorzeński Tymoteusz, w: Polski Stownik Biograficzny (dalej: PSB), t. 8, Wrocław-Warszawa-Kraków 1959-60, s. 329-330. Z kolei Wojciech Skarszewski objął diecezję chełmsko-lubelską w 1791 r. Nominację otrzymał w listopadzie 1790 r. po śmierci dotychczasowego biskupa chełmskiego, Macieja Garnysza, zob.: M. Deszczyńska, E. Zielińska, Skarszewski Wojciech Józef, w: PSB, t. 38, Warszawa-Kraków 1997, s. 50-61.

17 Dziennik Praw..., t. 1, s. XII.
} 
tzn. że każdy mianowany ordynariusz automatycznie stawał się senatorem ${ }^{18}$. Otrzymanie prekonizacji kanonicznej zatem miało następować w wyniku porozumienia się monarchy ze Stolicą Apostolską ${ }^{19}$. Wobec takiego rozumienia tej kwestii do senatu mogli wejść nominaci: Franciszek Malczewski i Tomasz Ostaszewski. Ponieważ obrady miały być najbardziej zbliżone do tradycji, Fryderyk August przystał na prośbę Raczyńskiego, by duchowni senatorowie mogli zorganizować się zgodnie z nią. Oznaczało to, że biskupi zasiedli według zasady pierwszeństwa ustalonej na podstawie starszeństwa diecezji - zgodnie z postanowieniami konstytucji sejmu lubelskiego z 1569 r. ${ }^{20}$ Kolejność ta przedstawiała się następująco: abp gnieźnieński, bp kujawski, poznański, płocki, chełmiński. Najmłodszy - wigierski zasiadł na końcu. Oczywiście dotyczyło to tylko biskupów, których diecezje znajdowały się w Księstwie. Po rozszerzeniu terytorium państwa o zdobycze z 1809 r. i zwiększeniu liczby posłów i senatorów dekretem Fryderyka Augusta z 24 lutego 1810 r. nastąpiła zmiana: drugie miejsce zajął bp krakowski, a za bpem wigierskim znaleźli się bp lubelski i kielecki, a na końcu bp chełmski unicki, którego diecezja została powołana w Księstwie w 1810. Tak zatem biskupi diecezji erygowanych po 1795 r. przez zaborców zasiedli za biskupami „starych diecezji”. Włączenie biskupa unickiego do senatu Księstwa - po raz pierwszy w dziejach tego Kościoła, miało wymiar szczególny i spotkało się ze specjalną oprawą. Potraktowano to wydarzenie jako dopełnienie woli Sejmu Wielkiego, który zadecydował o włączeniu do grona senatorów biskupa unickiego Teodozego Rostockiego, który już jednak nie zdążył zająć swojego krzesła ${ }^{21}$. W dniu 8 grudnia 1811 r. bardzo uroczyście wprowadzono biskupa unickiego do senatu, a całej uroczystości nadano znaczny rozgłos, m.in. przez publikację wystąpienia biskupa ${ }^{22}$. W tym przemówieniu Ciechanowski nie tylko dziękował za powołanie go do senatu, ale podkreślił też rolę Fryderyka Augusta, jako tego, który dopełnił woli sejmujących stanów przedrozbiorowej Rzeczypospolitej. Władze przywiązywały do tego wydarzenia tak wielką wagę, że w połowie obrad sejmu, 15 grudnia 1811 r., zorganizowano uroczystą mszę św. greckokatolicką w katedrze św. Jana dla króla, rządu i obu izb sejmu. W nabożeństwie celebrowanym przez Ciechanowskiego wzięły udział wszystkie władze kraju na czele z monarchą, senatorowie i posłowie oraz deputowani ${ }^{23}$. Włączenie do senatu bpa Ciechanowskiego przedstawiano jako wypełnienie Konstytucji 3 Maja, co stanowiło nawiązanie do tradycji Rzeczypospolitej przedrozbiorowej, zwłaszcza, że aktu tego dokonywał konstytucyjny następca tronu po Stanisławie Auguście Poniatowskim. Taka interpretacja było możliwa z uwagi na dekret Fryderyka Augusta z 10 października 1809 r.,

\footnotetext{
18 E.M. Ziółek, dz. cyt., s. 58; J. Skarbek, Biskupi senatorowie w dobie rozbiorów Rzeczypospolitej w Księstwie Warszawskim $i$ w Królestwie Polskim (wybrane zagadnienia), w: Kościót. Społeczeństwo. Kultura, red. J. Drob i in., Lublin 2004, s. 189.

19 Przy czym należy pamiętać o odległej w czasie proweniencji tej procedury. Polscy królowie wywodzili bowiem prawo do nominacji biskupów nie tylko z faktu patronatu nad katedrami, ale też dlatego, że, mianując biskupa, mianowali równocześnie senatora królestwa i na to chcieli mieć wpływ, zob.: W. Abraham, Prawne podstawy królewskiego mianowania biskupów w dawnej Polsce, w: Studia historyczne ku czci Stanisława Kutrzeby, t. 1, Kraków 1938, s. 4, 10-12.

20 J. Skarbek, dz. cyt., s. 190-191; J. Willaume, Fryderyk August jako ksią̇ę warszawski, Poznań 1939, s. 131-132.

21 S. Litak, Od reformacji do Oświecenia. Kościół katolicki w Polsce nowożytnej, Lublin 1994, s. 158.

22 „Gazeta Korespondenta Warszawskiego i Zagranicznego”, nr 99 (9.XII.1811), dodatek.

23 „Gazeta Korespondenta Warszawskiego i Zagranicznego”, nr 101 z 17.XII.1811.
} 
w którym przywracał do obiegu prawnego wszystkie te prawa przedrozbiorowe, które nie stały w sprzeczności z konstytucją Księstwa oraz Kodeksem Napoleona ${ }^{24}$.

Jedynym wyjątkiem od zasady automatyzmu zajmowania krzesła senatorskiego przez biskupów była sprawa biskupa lubelskiego, Wojciecha Skarszewskiego. Mimo że, jak było powiedziane, był on jednym z dwóch biskupów będących senatorami jeszcze w okresie przedrozbiorowym, to równocześnie ciągnęła się za nim kwestia wyroku śmierci za zdradę z 1794 r. ${ }^{25}$ Co prawda, wyrok ten Tadeusz Kościuszko zamienił na dożywotnie więzienie, a po klęsce powstania kościuszkowskiego biskup został uwolniony i powrócił do swojej diecezji, jednak pamięć o tych wydarzeniach trwała i pojawił się problem bardziej moralny niż prawny - jak honorować za zasługi dla kraju człowieka, który był sądzony za jego zdradę? Rada Ministrów w tym wypadku zaproponowała królowi, by wstrzymał nominację senatorską Skarszewskiego. Formalnie więc był on senatorem, ale nie zasiadał w senacie ${ }^{26}$.

Zgodnie z tradycją obrady trzech sejmów w Księstwie, w 1809, 1811 i 1812 r., odbywały się na Zamku w Warszawie i starano się dopełniać ceremoniału z czasów Rzeczypospolitej. Rozpoczęcie obrad następowało zatem w Sali Senatorskiej. Natomiast po wysłuchaniu przemówienia Fryderyka Augusta posłowie i deputowani udawali się do Izby Poselskiej. Obie izby sejmu obradowały oddzielnie i rygorystycznie przestrzegano tego obowiązku ${ }^{27}$.

Rok 1812 jest o tyle ważny, że w przededniu wojny z Rosją został zwołany trzeci w okresie Księstwa Warszawskiego sejm - nadzwyczajny. Było to całkowite nawiązanie do czasów przedrozbiorowych, sejm ten ukonstytuował się jako konfederacja 26 VI 1812 r., pod laską ks. Adama Kazimierza Czartoryskiego, a znaczną rolę odegrał tam bp wigierski i senator Jan Klemens Gołaszewski, jego zastępca ${ }^{28}$.

\section{Senat w Królestwie Polskim}

Królestwo Polskie, powstałe na kongresie wiedeńskim jako wyraz pewnego kompromisu między zaborcami, od początku z myślą połączenia unią personalną z Rosją, nie tylko nie miało być bytem suwerennym, ale też w znacznie mniejszym stopniu można je uważać za krok na drodze do pełnej niepodległości ${ }^{29}$. Konstytucja Królestwa została oktrojowana 27 listopada 1815 r., jednak poprzedzały ją ,Zasady do konstytucji”, opracowane przez Adama Jerzego Czartoryskiego jeszcze w maju tego roku. Ostateczna wersja konstytucji odbiegała od „Zasad...”, niemniej warto pamiętać, że w założeniach księcia nowa konstytucja powinna była być jak najbliższa Konstytucji 3 Maja. Senatowi chciał Czartoryski m.in. powierzyć obowiązek czuwania nad wolnością druku. Warto przy okazji wspomnieć, że senat Księstwa

\footnotetext{
24 Dziennik Praw..., t. 2, s. 87-88.

25 M. Deszczyńska, E. Zielińska, dz. cyt., s. 55.

26 E.M. Ziółek, dz. cyt., s. 60.

M. Kallas, Sejmy na Zamku w czasach Księstwa Warszawskiego (1809, 1811, 1812), Warszawa 1987, s. 53-57.

28 Tamże, s. 57-58; E. M. Ziółek, dz. cyt., s. 65.

29 Dość szybko okazało się, że nie wchodzi w grę przyłączenie tzw. „ziem zabranych” do Królestwa, jak to sobie wyobrażał książę Adam J. Czartoryski, zob.: L. Mażewski, O ciągłości między Księstwem Warszawskim i Królestwem Polskim (1807-1830), w: System polityczny, prawo i konstytucja Królestwa Polskiego 1815-1830, red. L. Mażewski, Radzymin 2013, s. 16-19.
} 
Warszawskiego został uznany za legalnie funkcjonującą instytucję i to uchwała tegoż senatu z 22 lipca 1815 r. potwierdzała uznanie Aleksandra I jako króla Polski ${ }^{30}$.

W nowej konstytucji, nadanej przez Aleksandra, do senatu odnoszą się artykuły 108-117 zawarte w II rozdziale tytułu IV ${ }^{31}$. Utrzymano w nich sporo rozwiązań z czasów Księstwa, przede wszystkim zasadę dożywotniości urzędu senatorskiego oraz tytuły senatorskie, jednak zmienił się skład izby. Konstytucja wprowadzała bowiem do grona senatorów książąt krwi cesarsko-królewskiej, którzy po ukończeniu 18 lat mieli prawo czynnego udziału w pracach senatu $^{32}$. Warto wspomnieć, że wielki książę Konstanty zrezygnował z godności senatorskiej, zachował ją natomiast najmłodszy z braci Aleksandra I, wielki książę Michał ${ }^{33}$. Konstytucja inaczej też określała liczbę senatorów, jako niemogącą przekraczać połowy ogólnej liczby posłów i deputowanych. Ponieważ tych było 128 (77 posłów i 51 deputowanych), to ich połowa wynosiła - 64 osoby. $Z$ tej liczby 9 było biskupami, 18 wojewodami i 37 kasztelanami. Liczba książąt krwi nie podlegała żadnym ograniczeniom. Sposób powoływania senatorów był dwustopniowy: król mianował spośród dwóch kandydatów wyłonionych przez sam senat i przedstawionych przez namiestnika. Nie dotyczyło to senatorów z Księstwa Warszawskiego, którym Aleksander I potwierdził nominacje, oraz biskupów, którzy wchodzili do senatu z urzędu. Natomiast trzeba dodać, że car nie przestrzegał do końca tej zasady. Spoza listy przygotowanej przez izbę włączył w poczet senatorów kilka osób, m.in. Wincentego Krasińskiego, Stanisława Sołtyka czy Józefa Lubomirskiego. W gronie senatorów Królestwa znalazły się także osoby, których początki kariery politycznej przypadały na lata jeszcze przedrozbiorowe, jak Piotr Bieliński, Stanisław Kostka Potocki, Józef Wybicki, Augustyn Gorzeński. Byli oni czynni też w okresie Księstwa Warszawskiego (w tej liczbie należy umieścić także biskupów: Ferdynanda Ciechanowskiego, Franciszka Malczewskiego, Jana Klemensa Gołaszewskiego) ${ }^{34}$. Dopiero także w Królestwie Polskim w senacie zasiadł biskup lubelski, Wojciech Skarszewski.

Konstytucja wprowadzała stopnie senatorstwa: najpierw zostawało się kasztelanem, a dopiero potem wojewodą. Natomiast artykuł 113 stanowił, że przewodniczyć pracom senatu miał najstarszy członek tego gremium, według przepisów zawartych w innych postanowieniach ${ }^{35}$. Prezesa mianował król. Konstytucja wprowadzała cenzusy: wieku - senator musiał mieć ukończone 35 lat i majątkowy - musiał opłacać co najmniej 2000 zł rocznego podatku ${ }^{36}$. Utrzymano nadzór senatu nad ważnością wyborów do izby poselskiej tudzież nad układaniem ksiąg obywatelskich, uzyskiwał on też dodatkowe prerogatywy w okresie regencji. Senat miał decydować o oddaniu pod sąd wyższych urzędników państwowych

30 A. Ajnenkiel, dz. cyt., s. 30; P. Łazor, dz. cyt., s. 347.

31 Dziennik Praw Królestwa Polskiego, t. 1, Warszawa 1816, s. 64-70.

32 Mówił o tym już artykuł 108, zob.: tamże, s. 64.

33 P. Łazor, dz. cyt., s. 348.

34 Tamże, s. 349.

35 Chodzi o dekret z 7/19 stycznia 1817 r., na mocy którego Aleksander I uznawał nominacje senatorskie Fryderyka Augusta i który jednocześnie regulował zasadę starszeństwa według dat nominacji senatorskich z Księstwa Warszawskiego, Dziennik Praw Królestwa..., t. 3, Warszawa 1817, s. 37-40. Można przypuszczać, że takie posunięcie było podyktowane chęcią odsunięcia od stanowiska przewodniczącego senatu księcia Adama Czartoryskiego, zob. P. Łazor, dz. cyt., s. 349.

36 Należy zauważyć, że książąt krwi nie dotyczyły te regulacje, Dziennik Praw Królestwa..., t. 1, s. 66. 
za uchybienia w wykonywaniu obowiązków, a w pełnym składzie i pod przewodnictwem prezesa stanowił sąd sejmowy dla rozpatrywania oskarżeń o zbrodnie stanu ${ }^{37}$.

Senat w Królestwie uzyskał szersze prerogatywy, jeśli chodzi o samą legislację, i widać tu wyraźny powrót do tradycji polskiego parlamentaryzmu, aczkolwiek z takimi mechanizmami, które chroniły przed zbyt daleko posuniętą wolnością sejmowania, jak np. ustawowe prowizorium budżetowe, które w przypadku Królestwa mogło trwać nie tylko dwa, ale nawet kilka lat. Konstytucyjne rozszerzenie kompetencji sejmu powodowało, że także senat miał możliwość debatowania nad poszerzonym spektrum spraw, jak projekty praw karnych, cywilnych, administracyjnych, nie tylko nad finansami państwa. Natomiast to panujący określał zakres spraw podejmowanych $\mathrm{w}$ danym posiedzeniu. Niemniej wprowadzone zostało też nowe rozwiązanie, że to od monarchy zależało, czy projekt ustawy (z wyłączeniem budżetu) będzie procedowany najpierw w izbie poselskiej, czy najpierw w senacie ${ }^{38}$. Była to sprytna formuła dająca możliwość uniknięcia zbyt daleko idącej debaty - przynajmniej w założeniu. W przypadku bowiem mianowanych przez króla senatorów można było liczyć na większą przychylność dla jego projektów. Projekt musiał wprawdzie przejść przez obie izby, ale ta druga w kolejności nie mogła nic w ustawie zmieniać, mogła tylko przedstawiony projekt przyjąć lub odrzucić. Wobec tego obie izby, a więc i senat, musiały wyłonić komisje do roztrząsania projektów. Były to trzy komisje: do praw skarbowych, cywilnych i kryminalnych, organicznych i administracyjnych. W senacie wybierano do każdej z nich po 3 senatorów. Komisje miały obowiązek współpracy z Radą Stanu, gdyż to ona odpowiadała za ułożenie projektów ustaw $^{39}$. Można powiedzieć, że jeśli w zamierzeniu Czartoryskiego miał nastąpić powrót do tradycji sejmowania w Polsce, to został on ograniczony zabezpieczeniami na rzecz panującego.

Niewątpliwym natomiast zerwaniem z tradycją stało się samo mianowanie, jak też kolejność zasiadania senatorów duchownych. To drugie zresztą spowodowane było kwestią wprowadzenia nowego porządku administracyjnego Kościoła w Królestwie Polskim w wyniku reformy 1818 r. ${ }^{40} \mathrm{~W}$ 64-osobowym senacie dla biskupów przypadło 9 krzeseł: 8 dla łacinników i jedno dla biskupa chełmskiego unickiego, co było zgodne z zapisami artykułów 14 i 41 konstytucji oraz zapisami Statutu Organicznego z 7/19 listopada 1816 r., gdzie m.in. został przedstawiony ostateczny skład senatu ${ }^{41}$. Wprawdzie w dyskusji nad niedoszłym projektem wprowadzenia do senatu biskupów sufraganów, która miała miejsce w lutym 1817 r., padło ze strony ministra Wyznań Religijnych i Oświecenia Publicznego, Stanisława Kostki Potockiego sformułowanie: „senat dawnego Królestwa Polskiego na wzór którego

\footnotetext{
37 Odnośnie do tej prerogatywy senatu mowa jest w 116 i 152 artykule konstytucji (Dziennik Praw Królestwa..., t. 1, s. 58, 92) oraz w Statucie Organicznym, (Dziennik Praw Królestwa..., t. 2, s. 289). Natomiast szczegółowe przepisy zostały wprowadzone, można powiedzieć, pod presją chwili - rozporządzeniem z 7/19 kwietnia 1827 r., w związku z procesem członków Towarzystwa Patriotycznego, Dziennik Praw Królestwa ..., t. 11, s. 455-507; H. Dylągowa, Towarzystwo Patriotyczne i sąd sejmowy 1821-1829, Warszawa 1970, s. 239-245.

38 Dziennik Praw Królestwa..., t. 1, s. 340 (art. 145 Statutu Organicznego).

39 A. Ajnenkiel, dz. cyt., s. 31-33.

40 Sama reforma, jej okoliczności, negocjacje, a także jej skutki zostały omówione w publikacji Anny Barańskiej pt.: Między Warszawa, Petersburgiem i Rzymem. Kościót a państwo w dobie Królestwa Polskiego, Lublin 2008.

${ }^{41}$ W art. 14 powtórzono zapisy z konstytucji Księstwa, mówiąc, że diecezji łacińskich będzie tyle, ile zostanie wyznaczonych województw, a dodatkowo jedna diecezja unicka, natomiast art. 41 stwierdzał, że senatorów mianuje król Dziennik Praw Królestwa..., t. 1. s. 10, 24. Statut Organiczny, tamże, t. 2, s. 269-290.
} 
teraźniejszy jest urządzony’^2, to jednak w przeciwieństwie do Księstwa Warszawskiego, które powtórzyło całą procedurę tradycyjną, poprzestano wyłącznie na zwyczajowym włączeniu biskupów do senatu. Już natomiast kwestia samej nominacji została potraktowana odmiennie. Mianowicie senatorem nie zostawało się automatycznie z urzędu, otrzymując nominację biskupią. Potrzebny był też osobny dekret nominacyjny na godność senatorską. Aleksander I wprawdzie zatwierdził wszystkie nominacje senatorskie z czasów Fryderyka Augusta, ale dekretem z 7/19 stycznia 1817 r. zastrzegł sobie dla biskupów, których miałby powoływać w późniejszym czasie, podwójną procedurę, co oznaczało, że można było być biskupem ordynariuszem i nie być senatorem. Podejmując taką decyzję, Aleksander eliminował współudział w mianowaniu senatorskim czynnika zagranicznego, za jaki uważał papieża. Wydaje się, że car nie do końca rozumiał mechanizm powoływania biskupów-senatorów, natomiast chciał wprowadzić zasadę, w myśl której godność senatorska stawała się szczególnym wyróżnieniem ze strony monarchy i należało na nią zasłużyć. Oznaczało to możliwość tworzenia niebezpiecznych precedensów - biskup znajdujący się w jakimkolwiek konflikcie z monarchą mógł nie zostać włączony w skład senatu. To spotkało np. biskupa krakowskiego Karola Skórkowskiego, prekonizowanego 27 VII 1827 r., który objął rządy w diecezji 25 stycznia 1830 r. Ponieważ był krytykiem projektu prawa małżeńskiego forsowanego przez Mikołaja I, nie otrzymał nominacji senatorskiej i został włączony do senatu dopiero 14 maja $1831 \mathrm{r}$. suwerenną decyzją sejmu powstańczego ${ }^{43}$. Konieczność podwójnej nominacji powodowała również upływ czasu pomiędzy obiema czynnościami, który dochodził niekiedy od kilku miesięcy (bp augustowski Ignacy Czyżewski, bp kujawski Andrzej Wołłowicz, bp płocki Adam Prażmowski) do roku (bp sandomierski Adam Prosper Burzyński, bp kujawski Józef Koźmian, bp podlaski Jan Gutkowski) lub nawet półtora roku - bp lubelski Józef Dzięcielski. Nie jest wykluczone, że przeciąganie sprawy nominacji senatorskiej również było podyktowane próbą wymuszenia na biskupach określonych zachowań ${ }^{44}$. Natomiast kolejność zasiadania w senacie uregulował wspomniany dekret, wprowadzając zasadę starszeństwa nominacji, zamiast dotychczasowej - starszeństwa diecezji. Wynikało to z planowanej reformy kościelnej, a szczególnie z powołania już w 1817 r. arcybiskupa warszawskiego - który, mimo zwierzchnictwa nad całym Kościołem w Królestwie Polskim, musiałby zasiadać np. za biskupem płockim. Wprowadzając zasadę starszeństwa nominacji, usunięto ten problem, powodowało to również, przy okazji kolejnych nominacji, przesuwanie się „starszych” biskupów - senatorów ku pierwszym krzesłom ${ }^{45}$. Natomiast pierwszym biskupem-senatorem był arcybiskup warszawski. Tym niemniej należy podkreślić, że o ile system kolejności krzeseł senatorskich biskupów w Rzeczypospolitej przedrozbiorowej, a także Księstwie Warszawskim, odwoływał się do tradycji, podkreślając starożytność diecezji, to w Królestwie Polskim - premiował zasiadanie w izbie.

Warto dodać, że w omawianym okresie wyraźnie widać statystyczny wzrost liczby senatorów duchownych w relacji do senatorów świeckich. Było to oczywiście wynikiem innej organizacji senatu, zmniejszenia liczby senatorów w ogóle. I tak przed 1772 r. na 153

\footnotetext{
42 J. Skarbek, dz. cyt., s. 192.

43 Tamże, s. 194-195.

44 O trudnych relacjach kościelno-państwowych w Królestwie Polskim zob.: A. Barańska, dz. cyt., 437-606.

45 J. Skarbek, dz. cyt., s. 196. Zamieszczona na tej stronie tabela obrazuje przemieszczanie się biskupów na krzesłach senatorskich w kolejnych kadencjach sejmu.
} 
senatorów było w tym gronie 17 biskupów (11,1\%), a w 1790 na 130 senatorów - 14 biskupów (10,8\%). Natomiast w Księstwie Warszawskim biskupi stanowili 1/3 składu senatu, zajmując w 1807 r. 6 miejsc, a od 1810 r. - 10, co wprost wynikało z zapisów konstytucji. W Królestwie ich liczba spadła do 1/7 składu izby z uwagi na podniesienie liczby senatorów i wyniosła 9 miejsc na 64 osoby i również liczba ta była dość sztywno zapisana w konstytucji Królestwa Polskiego ${ }^{46}$.

Przebieg obrad senatu, podobnie jak całego sejmu, nie odbiegał specjalnie od tradycji. Obrady trwały 4 tygodnie, rozpoczynały się nabożeństwem w katedrze św. Jana w Warszawie, któremu przewodził arcybiskup warszawski. Obie izby spotykały się w Sali Senatu na posiedzenie inaugurujące. Tu miała miejsce mowa tronowa króla. Po wygłoszeniu mów i powitań oraz zaprzysiężeniu marszałka izby poselskiej oraz wysłuchaniu raportu o stanie państwa, dalsze obrady toczyły się w oddzielnych salach ${ }^{47}$.

Ostatnim akordem w pracy senatu Królestwa Polskiego było powstanie listopadowe. Niektórzy z senatorów włączyli się w działalność powstańczą, jednak większość przejawiała przekonania zachowawcze, nie popierała detronizacji Romanowów i nie angażowała się specjalnie $^{48}$. Po upadku powstania część senatorów, najbardziej zaangażowanych w działalność polityczną w latach 1830-1831, udała się na emigrację, a sam sejm Królestwa Polskiego przestał istnieć.

\section{Podsumowanie}

Rola polityczna senatorów w omawianym okresie była mniejsza niż w czasach przedrozbiorowych. Mimo zachowania elementów tradycyjnych, jak nazewnictwo czy ceremoniał, tak na prawdę mieli oni za zadanie jedynie reprezentować społeczeństwo w granicach, które ściśle wyznaczyli monarchowie. I od monarchów zależało, jak wielki mógł to być zakres. Warto zwrócić uwagę, że w Księstwie powiązanie liczby senatorów z ilością jednostek administracyjnych, choć nie przekładało się realnie na reprezentację poszczególnych departamentów, to mogło sugerować taki związek. Ale już w Królestwie Polskim nastąpiło całkowite zerwanie z takimi zależnościami, nawet jeżeli dotąd były one symboliczne. I choć konstytucja Królestwa Polskiego w swoich zapisach nadawała senatowi większe znaczenie, to znów realny kształt tego znaczenia budowała wola monarchy. O ile więc Fryderyk August, który dobrze znał przedrozbiorowy system polityczny Rzeczypospolitej, miał nawet wolę, w zakresie zgodnym z konstytucją Księstwa, przywrócić jednak tradycyjne miejsce senatu, to już nie wchodziło to w grę w państwie rządzonym przez Romanowów. Dla Aleksandra I (a tym bardziej Mikołaja I) ustrój parlamentarny był jedynie nowocześnie wyglądającą oprawą rządów absolutnych. Chodziło więc o to, aby jeśli nie cały parlament, to przynajmniej senat uczynić bezwolnym narzędziem w ręku sprawującego władzę. Faktycznie senat Królestwa Polskiego cechowała mniejsza aktywność i w przeciwieństwie do izby poselskiej, większa ugodowość w stosunku do monarchy. Należy jednak podkreślić, że kilkakrotnie zachował on niezależność. Szczególnym takim przypadkiem był słynny sąd sejmowy w 1828 r. Senat

\footnotetext{
46 J. Skarbek, dz. cyt., s. 197.

47 P. Łazor, dz. cyt., s. 352.

48 O senacie w okresie powstania listopadowego zob.: M. Karpińska, ,, Nie ma Mikołaja!’' Starania o kształt sejmu w powstaniu listopadowym 1830-1831, Warszawa 2007, s. 148-210.
} 
zdobył się na decyzję sprzeczną z oczekiwaniem cara ${ }^{49}$. Wydaje się, że wcale nie będzie przesadą stwierdzenie, iż wiele ze zmian wprowadzanych zarówno przez konstytucję napoleońską, jak i Królestwa wcale nie było nowocześniejszych niż obowiązujące w okresie przedrozbiorowym. Dodatkowo senat blokowało dosyć zasadniczo ograniczenie władzy ustawodawczej w ogóle, szczególnie w Księstwie Warszawskim. Nawiązania do tradycji wynikały więc raczej z próby - choćby symbolicznego - wykazania ciągłości z okresem przedrozbiorowym. Za symboliczny fakt należy uznać, że zniesienie senatu na następnych kilkadziesiąt lat, do roku 1919, było wynikiem klęski powstania listopadowego i ostatecznego rozprawienia się Mikołaja I z resztkami polskiej państwowości i jej tradycji.

\section{Bibliografia}

\section{Źródla}

Archiwum Główne Akt Dawnych (AGAD), Archiwum Publiczne Potockich, sygn. 249

Dziennik Praw Królestwa Polskiego, t. 1-2, Warszawa 1816, t. 3, Warszawa 1817, t. 11, Warszawa 1827.

Dziennik Praw [Księstwa Warszawskiego], t. 1-2, Warszawa 1810.

„Gazeta Korespondenta Warszawskiego i Zagranicznego”, 1811.

\section{Literatura}

Abraham W., Prawne podstawy królewskiego mianowania biskupów w dawnej Polsce, w: Studia historyczne ku czci Stanisława Kutrzeby, t. 1, Kraków 1938, s. 1-12.

Ajnenkiel A., Historia sejmu polskiego, t. 2, cz. 1: W dobie rozbiorów, Warszawa 1989.

Barańska A., Między Warszawa, Petersburgiem i Rzymem. Kościół a państwo w dobie Królestwa Polskiego, Lublin 2008.

Czubaty J., Księstwo Warszawskie (1807-1815), Warszawa 2011.

Deszczyńska M., Zielińska E., Skarszewski Wojciech Józef, w: Polski Słownik Biograficzny (dalej: PSB), t. 38, Warszawa-Kraków 1997, s. 50-61.

Dylągowa H., Towarzystwo Patriotyczne i sad sejmowy 1821-1829, Warszawa 1970.

Getka-Kenig M., Ojcowie ,wskrzeszonej” ojczyzny. Senat w rzeczywistości społeczno-politycznej Księstwa Warszawskiego, Warszawa 2013.

Godechot J., Les institutions de la France sous la Révolution et l'Empire, Paris 1951.

Kallas M., Konstytucja Księstwa Warszawskiego. Jej powstanie, systematyka i główne instytucje w związku z normami szczegółowymi i praktyka, Toruń 1970.

Kallas M., Sejmy na Zamku w czasach Księstwa Warszawskiego (1809, 1811, 1812), Warszawa 1987.

Karpińska M., ,Nie ma Mikołaja!” Starania o kształt sejmu w powstaniu listopadowym 1830-1831, Warszawa 2007.

Litak S., Od reformacji do Oświecenia. Kościół katolicki w Polsce nowożytnej, Lublin 1994. Łazor P., Senat w Królestwie Polskim (1815-1830). Organizacja, kompetencje i funkcjonowanie, w.: System polityczny, prawo i konstytucja Królestwa Polskiego 1815-1830, red. L. Mażewski, Radzymin 2013, s. 347-359.

49 O procesie członków Towarzystwa Patriotycznego, zob.: H. Dylągowa, dz. cyt., s. 214-324. 
Mażewski L., O ciagłości między Księstwem Warszawskim i Królestwem Polskim (1807-1830), w: System polityczny, prawo i konstytucja Królestwa Polskiego 1815-1830, red. L. Mażewski, Radzymin 2013, s. 13-26.

Morabito M., Bourmaud D., Historia konstytucyjna i polityczna Francji (1789-1958), tłum. A. Jamróz, Białystok 1996.

Nowacki J., Gorzeński Tymoteusz, w: PSB, t. 8 Wrocław-Warszawa-Kraków 1959-60, s. 329-330.

Rostocki W., Z badań porównawczych nad ustrojem administracyjnym Księstwa Warszawskiego i Francji, „Czasopismo Prawno-Historyczne”, 13/1961, z. 1, s. 105-126.

Skarbek J., Biskupi senatorowie w dobie rozbiorów Rzeczypospolitej w Księstwie Warszawskim i w Królestwie Polskim (wybrane zagadnienia), w: Kościót. Spoteczeństwo. Kultura, red. J. Drob i in., Lublin 2004, s. 187-199.

Sobociński W., Historia ustroju i prawa Księstwa Warszawskiego, Toruń 1964.

Willaume J., Fryderyk August jako książę warszawski, Poznań 1939.

Zahorski A., Napoleon - człowiek wieku, w: Europa i świat w epoce napoleońskiej, red. M. Senkowska-Gluck, Warszawa 1977, s. 9-85.

Ziółek E. M., Między tronem i ołtarzem. Kościót i państwo w Księstwie Warszawskim, Lublin 2012. 